ADDIN, Volume 11, Number 2, August 2017

\title{
TERMINATION OF WAHDATUL WUJUD IN ISLAMIC CIVILIZATION IN ACEH: Critical Analysis Of Ithaf Al-Dhaki, The Works Of Ibrahim Kurani
}

\author{
Ismail Fahmi Arrauf Nasution \\ IAIN Zawiyah Cot Kala Langsa, Aceh, Indonesia \\ ismailfahmiarraufnasution@yahoo.co.id
}

\section{Abstract}

Wabdatul Wujud or Unity of Being is a sufi doctrine that is in accordance with the well-known, inclusive and permissive views of the people of Nusantara. The teaching has proven to be an important part in realizing the peaceful and harmonious civilization of the Islamic archipelago. Unfortunately when orthodox theology doctrines which nuanced exclusive and radical dominated the Muslim intellectual discourse of archipelago, the doctrine of Wahdatul Wujud become excluded and even terminated from the stage of Islamic intellectualism of archipelago. This paper wants to evaluate critically the work of Ibrabim Kurani, Ithäf al-Dhakî bi Shabr al-Tubfah al-mursalah ila al-Nabi which was written intentionally to explain the papers of Mubammad Fadhullah al-Burhanpuri entitled Al-Tuhfah almursalab ila al-Nabi Which discusses the teachings of Wabdatul Wujud that had been spread in the archipelago. This Ibrabim Kurani's works is necessasry to be evaluated though it is generally accepted as the synthesis of Wabdatul Wujud according to orthodox theology, but 
factually it has a very significant role in reducing this doctrine so that Wabdatul Wujud becomes a foreign doctrine in the archipelago. In this study the authors found some epistemological and academic error committed by Ibrabim Kurani to the doctrine of Wabdatul Wujud in his book. The author expects Wabdatul Wujud could be revived in scientific and academic discourse as a solution to counter the teachings of exclusive and radical Islam in order to realize a peaceful and democratic Islam as had happened in the history of Islamic civilization in archipelago.

Keywords: Ibrabim Kurani, Ithäf al-Dhakî, Archipelago Islamic Civilization, 'Urafa, Theolog.

\section{Abstrak}

WAHDATUL WUJUD DALAM PERADABAN ISLAM DI ACEH: ANALISIS KRITIS TERHADAP ITHAF ADH-DHAKI, KARYA IBRAHIM KURANI. Wabdatul Wujud adalab ajaran yang sesuai dengan penghayatan dan pandangan bidup masyarakat Nusantara yang terkenal bersifat inklusif dan permisif. Ajaran tersebut telah terbukti menjadi bagian penting dalam mewujudkan peradaban Islam Nusantara yang damai dan harmonis. Namun setelah ajaran-ajaran teologi ortodoks yang bernuansa inklusif dan radikal mendominasi diskursus intelektual Islam Nusantara, Wabdatul Wujud menjadi terkucilkan dan babkan terbapuskan dari pentas intelektualisme Islam Nusantara. Tulisan ini ingin melakukan evaluasi kritis terhadap karya Ibrabim Kurani, Ithäf al-Dhakî bi Shabr al-Tuhfah al-Mursalah ilā al-Nabî yang ditulis dengan tujuan mensyarah makalah karya Muhammad Fadhullah al-Burbanpuri berjudul Al-Tubfah al-Mursalah ilā al-Nabî̀ yang membahas tentang ajaran Wabdatul Wujud yang disebarkan di Nusantara. Karya Ibrabim Kurani itu penting dievaluasi karena sekalipun diterima secara umum sebagai sintesa ajaran Wabdatul Wujud dengan ajaran teologi ortodos, namun ternyata memiliki peran yang sangat signifikan dalam mereduksi ajaran tersebut sehingga manjadi asing di masyarakat Nusantara. Dalam penelitian ini 
penulis menemukan beberapa kegalatan epistemologis dan akademis yang dilakukan Ibrabim Kurani terbadap ajaran Wabdatul Wujud dalam karyanya itu. Penulis mengharapkan Wabdatul Wujud dapat direvivalisasi dalam diskursus keilmuan dan akademik sebagai solusi terbadap ajaran-ajaran Islam yang radikal dan inklusif guna mewujudkan kembali Islam yang damai dan demokratis sebagaimana pernah terjadi dalam sejarah peradaban Islam Nusantara.

Kata Kunci: Ibrahim Kurani, Ithäf al-Dhakî, Peradaban Islam Nusantara, 'Urafa, Teolog.

\section{A. Introduction}

The archipelago consisted of people who were gentle, tolerant and open-minded. The positive nature makes them so easy to accept and filter the teachings and insights that match their character. The first period of Islam entered the archipelago in a gentle way and put forward a cultural approach. Through that way Islam is warmly welcomed and accepted with open arms by the people of the archipelago.

All schools and sects in Islam are openly discussed by promoting the principle of peace and tolerance. The teachings are synonymous with the aspiration, taste and culture of the devoted community so as to produce a unified understanding of the Absolute, humans and nature become dominant in the practice and teachings in Islamic civilization of Archipelago.

That's why Wahdatul Wujud where its' principle of teaching in line with the outlook of Melayu accepted, practiced and widely taught in the life of the people of the archipelago. But after the teachings of Islam are possessed more the nature of Arab society who came through the indigenous students of the Archipelago who went to the Middle East in certain places in search of the Islamic knowledge, Islamic teachings in archipelago becomes exclusive, radical 
and orthodox. Along with that, the doctrinal teachings that are identical to the inclusive and democratic principles are marginalized, either in extreme ways or political ways.

This paper wishes to show the significance of Wahdatul Wujud in Islamic civilization in Aceh and its ending in the reduction into the theological perspective of Abdurrauf asSingkili and his teacher Ibrahim Kurani. Therefore this paper needs to critically evaluate the studies in Ibrahim Kurani's book Ithäf al-Dhakî bi Shabr al-Tubfah al-Mursalah ilā al-Nabî to prove the intended reduction. The author wants to show that in the article there has been a distortion of the purity of the doctrines of Wahdatul Wujud. The book has reduced Wahdatul Wujud into a theological perspective that makes society misunderstand the doctrine that once made peace and guard the harmony in the civilization of Acehnese and archipelago. At the end of the discussion the authors will show the significance and relevance of Wahdatul Wujud revivalization as the foundation of the paradigm of inclusiveness, tolerance and democratization of science and society as a continuation of the harmonious archipelago Islamic civilization.

\section{B. Discussion}

\section{Significance of Wahdatul Wujud in Aceh Civilization}

Although scientific data is only able to show the Samudera Pasai as the oldest Islamic civilization in Aceh, even the archipelago, but from folklore and recent evidence, it is difficult to argue that Peureulak had first built an Islamic civilization than the Samudera Pasai. ${ }^{1}$ Even some scholars

\footnotetext{
${ }^{1}$ Regarding the theories of the advance of Islam to Archipelago, see Abdurrohman Kasdi, "The Role of Walisongi in Developing Islam Nusantara" Jurnal Addin, Vol. 11. No. 1, February 2017, 3-6. See AzyumardiAzra, JaringanUlama, (Bandung, Mizan, 1999), 25.
} 
try to prove Jeumpa is the oldest Islamic civilization that has advanced in $777 \mathrm{AD}^{2}$

Apart from that, as far as Aceh civilization is concerned, Islam was not only the merely foundation and practices of the Acehnese but it was also the object of evaluation and critical studies. The subjects of Islamic knowledge were studied comprehensively such as jurisprudence, logic, philosophy, theology, mysticism and other Islamic sciences. ${ }^{3}$ Likewise, Islamic literatures were developed in various parts of the Muslim world, like Africa, Middle East, South Asia, where they were discussed, commented criticized and reproduced.

Not only that, the discourses of Islamic scholarship are produced in an original way with the approach of Aceh culture in the perspective of local intellectuals. These products are not only a reference to local Aceh but also in various parts of the Islamic world. So that it can be said that Aceh civilization really can not be separated from the development of Islamic scholarship.

The openness of Aceh to the various scientific and religious sects in religion can not be separated from the open attitude of the people who are willing to accept the differences. One of the teachings that have developed and contributed much to the civilization of society is Wahdataul Wujud. The teachingis in accordance with the soul of the community who always live and realize that there is unity that can not be separated between humans, nature and the Absolute.

${ }^{2}$ See A. Hasjmy, Sejarah Masuk dan Berkembangnya Islam di Nusantara, (Jakarta: Al-Ma'arif, 1981), 153-155.

${ }^{3}$ Baharuddin Ahmad, "Sastra Melayu", Seyyed Hossein Nasr (ed.), Ensiklopedi Tematis Spiritualitas Islam: Manifestasi, transl. Mizan Translation Team (Bandung: Mizan, 2003), 478. 
Wahdatul Wujud is a doctrine attributed to the great name of its founder Muhyiddin Ibn 'Arabi. The teaching has been studied in Aceh since the late Samudra Pasai Sultanate ${ }^{4}$ and the early and middle period of the Sultanate of Aceh Darussalam.

According to traceable historical roots, Wahdatul Wujud has been studied openly at the Blang Peuria Islamic college near the center of the Samudera Pasai Sultanate. The Blang Peuria has successfully produced a philosophical Sufi ('urafâ) like Hamzah Fansuri ${ }^{5}$ and Shamsuddin al-Sumatrani. Both figures for a long time became the highest religious leader (qadhî malik al-'adl) in Aceh Darussalam Sultanate. It can be said, that 'urafā, the followers and the teachers of Wahdatul Wujud became the highest religious leader (qadhî malik al' $a d l$ in the Sultanate of Aceh Darussalam till the reign of Iskandar Muda. ${ }^{6}$

As it is known that Aceh Darussalam Sultanate gained its glory during the time of Iskandar Muda. Thus Wahdatul Wujud is a teaching that has contributed greatly to the civilization of Acehnese society. ${ }^{7}$ Aceh Darussalam until now

${ }^{4}$ Miftahul Ula, "Simbilisme Bahasa Sufi: Kajian Hermeunetika terhadap Puisi Hamzah Fansuri”, Religia, Vol. 19, No. 2, October 2015, 35. See A. Hasjmy Ruba'i Hamzah Fansuri, (Kuala Lumpur: Dewan Bahasa dan Bahasa Pustaka Kementerian Pelajaran Malaysia, 1976), 1.

${ }^{5}$ The author believe that Hamzah Fansuri's origin is Pasai whereas the region was also called Syahr Nuwi. See, Dr. Liau Yock Fang, Sejarah Kesustraan Melayu Klasik, (Jakarta: Rerlangga, 1993), 43. Also see Abdul Hadi WM in Hamzah Fansuri Bapak Sastra dan Bahasa Melayu, ed. Abdul Hadi WM and LK Ara (Jakarta: Lotlaka, 1981), 15.

${ }^{6}$ Hamid Nasuhi Zein, "Al-Tasawwuf wa al-Turuq al-Sufiyyah fi Indunisiya", Studia Islamica, Vol. 3, No. 3, 1996, 149-150. See also Eri Rostaria, "Hubungan Islamisasi Pendidikan Islam pada Masa Kesultanan Aceh", Studia Islamica, Vol. 3, No. 1, 1996, 129-130.

7 Darwis A. Soelaiman, "Aceh dalam Konteks Dunia Melayu”, in Darwis A. Soelaiman (ed.), Warisan Budaya Melayu-Aceh, (Banda Aceh: PUSMA, 2003), 114. 
become the pride of the community, especially in the triumph of religious field. Thus, either consciously or unconsciously, the romance of Wahdatul Wujud in the past influence the religious view of Aceh people until now.

Those 'urafä, followers and teachers of Wahdatul Wujud as the highest leader of religion in the Sultanate of Aceh Darusssalam has bequeathed many contributions in the field of religion. In particular Syamsuddin al-Sumatrani who has given birth to an Islamic law that became a legal reference throughout the period of the Sultanate of Aceh Darussalam and up to this day the law is still a dream of some people of Aceh as the ideal law.

The great contribution of 'urafā can not be separated from the principle of their teaching, Wahdatul Wujud. Though considered controversial by some scholars and literalist-minded theologians, it is actually a very beautiful, tolerant and unifying doctrine. Not only able to unite people consisting of various mindsets and principles of doctrine, Wahdatul Wujud can present the realization that man, nature and the Absolute can not be separated.

Wahdatul Wujud was openly opposed by Nur al-Din al-Raniri when he served as supreme leader of religion in the Sultanate of Aceh Darussalam during the reign of Iskandar Tsani. The literary-minded cleric issued an inhumane recommendation to the teacher and and follower of Wahdatul Wujud. Though the teaching has proven to play animportant role in realizing tolerance in society.

At the time of Iskandar Tsani in power, the authority of political power was actually used to root out Wahdatul Wujud. After Iskandar Tsani's death, his wife Sulthanah Safiatuddin reopened the space for Wahdatul Wujud by appointing Sayful Rijal from Minangkabau - a Wahdatul Wujud adherent - into the supreme religious leader. But not last long. Upon returning 
Abdurrauf as-Singkili, an Aceh origin, from studying in the Middle East, he was asked to become the supreme leader of religion. At that time, Wahdatul Wujud became a polemic in society. Some people who are literal-minded, claim Wahdatul Wujud as a heresy. ${ }^{8}$ Others acknowledge that the doctrine is not heretical but merely worthy of being followed and taught to certain people who have mastered Islamic scholarship.

Abdurrauf as-Singkili is not a responsive and reactive scholar in handling polemics in society, ${ }^{9}$ especially polemics related to his field, that is religious matters. He sent some people who feel uneasy with Wahdatul Wujud doctrine to ask a fatwa to a great scholar in Madinah who is also a former teacher of Abdurrauf as-Singkili himself, Ibrahim Kurani.

In response to the request, Ibrahim Kurani wrote a book named Ithäf al-Dhakî bi Shahr al-Tubfah al-Mursalab ilā alNabî. From the title it can be known that the book contains an explanation of a paper written by a wise teacher and follower of Wahdatul Wujud from India named Muhammad Fadhullah al-Burhanpuri. Al-Tubfah al-Mursalah ilā al-Nabî is a paper written by Fadhullah al-Burhanpuri spread by Wahdatul Wujud follower in Aceh and archipelago.

One of the wise teachers and followers of Wahdatul Wujud in Samudra Pasai and he was the highest religious leader in Aceh Darussalam happened to write a commentary to the work. The contents are an explanation of Martabat Tujub (the seven dignities) which is part of Wahdatul Wujud's teachings.

${ }^{8}$ Kautsar Azhari Noer, "Hermeunetika Sufi: Sebuah Kajian atas Pandangan Ibn 'Arabi tentang Takwil al-Qur'an”, Kanz Philosophia, Vol. 2, No. 2, February 2013, 310.

${ }^{9}$ Amirul Hadi, Aceh: Sejarah, Budaya dan Tradisi, Jakarta: Yayasan Pustaka Obor Indonesia, 2010), 153. 
Ibrahim Kurani is a scholar who mastered many literatures ranging from figh, philosophy, theology and mysticism. But unfortunately Ithäf al-Dhakî has missed the target. In terms of the title of the book we know that it is intended to respond to Al-Tuhfah al-Mursalab ilā al-Nabî but in its content, the author is trapped in philosophical discussion which is irrelevant and insignificant.

Apart from that, what is more important for Ibrahim Kurani to respond is not Muhammad Fadhullah alBurhanpuri's paper. Because Wahdatul Wujud has developed in Aceh and the archipelago long before Al-Tubfah al-Mursalab ilà al-Nabî spread in the archipelago.

\section{Reduction of Wahdatul Wujud: Critical Study over Ithāf al-Dhakî}

Ibrahim Kurani is an intellectual who mastered many fields of sciences such as hadith, theology, philosophy, mysticism and others. As mentioned above that Ibrahim Kurani criticized the interpretation of the 'urafā which fled from the context as Ibn Taymiyya accused' urafa of being perverted for interpreting the Holy Text (al-Qur'an and alHadith) incompatible with the contextual meaning. Ibrahim Kurani disagrees with Ibn Taymiyya ${ }^{10}$ on the grounds that there is a possibility of incompatibility of the Sufi inner meaning with the textual meaning of the verse. However, Ibrahim Kurani did not explain the reason for the discrepancy. Though he himself had previously stated that every verse of the Qur'an has various levels of understanding. ${ }^{11}$

Personally, Ibrahim Kurani does not question the inconsistency of the textual meaning with the contextual

${ }^{10}$ Oman Fathurrahman, Ithaf Al-Dhaki: Tafsir Wabdatul Wujud Bagi Muslim Nusantara, (Bandung: Mizan, 20012), 77.

11 "Setiap ayat memiliki enam puluh rubu penafsiran". See Oman Fathurrahman, Ithaf Al-Dhaki, 71. 
meaning with the condition that it does not violate the grammar. Regarding this condition he criticizes Ibn Hajar's view which attacking some Sufis whom he deems to be inconsistant in their textual interpratation with the context which results to false interpratation since the interpratation created was out of context. Ibrahim Kurani opposed to Ibn Hajar's criticism because he thought there was no grammatical errors. ${ }^{12}$

It should be pointed out that the statement of "urafa" is the result of spiritual sight and experience. Nevertheless, Ibrahim Kurani's mistake in this matter, as a whole, is that he does not claim that the textual meaning and the contextual meaning of a verse with other verses must be consistent, not the consistency of textual and contextual meaning in a single verse only. Whereas previously he had accepted the view of Abu Hamid al-Ghazali that the textual meaning of the verse should not be contrary to textual meaning of other verses. But he emphisized on the grammatical issue in understanding the textual meaning. ${ }^{13}$ Whereas previously he had accepted the view of Abu Hamid al-Ghazali that the textual meaning of the verse should not be contrary to textual meaning of other verses. But he emphisized on the grammatical issue in understanding the textual meaning. ${ }^{14}$

Above all, in this case, Ibrahim Kurani considers the spiritual experience of 'urafä with the reference of the Sacred Text. The work like this is the work of a theologian, which makes the Holy Text as the first source. Though he himself

${ }^{12}$ Ibid., 79-80.

${ }^{13}$ Urafa methodology of interpretation, see Kautsar Azhari Noer, "Hermeunetika Sufi: Sebuah Kajian atas Pandangan Ibn 'Arabi tentang Takwil al-Qur'an”, Kanz Philosophia, Vol. 2, No. 2, December 2012.

${ }^{14}$ Oman Fathurrahman, Ithaf Al-Dhaki, 72. 
in Ithäf al-Dhakî has acknowledged that the Qur'an can be interpreted with various perspectives and various levels. ${ }^{15}$

If Ibrahim Kurani's initial consideration was the acceptance that the main philosophical foundation is reason, the main basis of 'urafā' is the spiritual experience, ${ }^{16}$ and the theoretical basis of the theologian is the Qur'an, ${ }^{17}$ so he does not have to make any judgment on Muhammad Fadhullah al-Burhanpuri's Wahdatul Wujud.

The ones who reported Wahdatul Wujud's development in the Melayu country is absolutely theologically minded. Otherwise they would not report to Ibrahim Kurani because certainlythey would make a theological assessment of $\mathrm{Al}$ Tubfah al-Mursalah ilā al-Nabî. If they had no theological view, then the report would not be submitted to Ibrahim Kurani. So it can be said that those who reported and had objection on Wahdtul Wujud as well as Ibrahim Kurani himself are the ones who should be categorized as theologians. Even Abdurrauf as-Singkili is also a theologian. The proof is that he studied religious sciences from theologian, Ibrahim Kurani. Besides that, Abdurrauf as-Singkili's famous book Tanbih al-Masyî also contains an editorial redaction which reduced Wahdatul Wujud. ${ }^{18}$

Based on his claim that the Qur'anic verses are multifaceted, Ibrahim Kurani focuses more on the hadiths used by 'urafä in order to explain their belief in Wahdatul Wujud. But the denial and criticism of the scholars to 'urafa in the

${ }^{15}$ Aksin Wujaya, "Hermeunetika Al-Qur'an: Memburu Pesan Manusiawi dalam Al-Qur'an, Ulumuna, Vol. XV, No. 2, December 2011, 206.

${ }^{16}$ Muhammad Nur, "Takwil dalam Pandangan Mulla Sadra", Kanz. Philosophia, Vol. 2, No. 2, Desember 2012, 63.

${ }^{17}$ Ismail Fahmi Arrauf Nasution, "Mencerna Akar Filsafat dalam Islam“, Ulumuna, Vol. 17, No. 1, Juni 2013, 7.

${ }^{18}$ See Oman Fathurrahman, Tanbih Al-Masyi: Menyoal Wabdatul Wujud: Kasus Abdurrauf Singkel di Aceh Abad 17, (Bandung: Mizan, 1999). 
understanding of the hadiths is generally addressed to the 'literalist-minded scholars'. Ibrahim Kurani's criticisms for the literalists are too long for a single hadith. So Ithäf alDhakitgoes beyondit's genuine purpose that is to explain alTubfah al-Mursalah ilā al-Nabî.

Ibrahim Kurani's criticism over the ahlul hadith is insignificant and irrelevant. Because the ahlul hadith scholars are not deserved to explain the hadith in the perspective of Wahdatul Wujud. These criticisms do not really matter if Ibrahim Kurani had from the beginning understood that the 'urafä, philosopher and theologian's mindset was different. The basis of the knowledge of 'urafa is the spiritual, the use of mind and sacred text accordingly to their spiritual experience. The basis of the philosopher's knowledge is reason, their spiritual experience and the sacred texts are used as far as they are reasonable. While the theologians accept only philosophy and 'irfan ${ }^{19}$ as far as they are in accordance with the sacred text which is generally understood literally.

The last sentence of the paragraph above needs to be underlined because the way of understanding the sacred text depends on everyone's respective mindset. To see an object or to hear a single news can make many diifferent views, let alone sacred text or hadith. So the perspective of Ibrahim Kurani in criticizing the literalists in the interpretation of the hadiths that are often used by 'urafā did not give much benefit because the literarist is certainly different in interpreting the hadith from the contextualist. This difference lies not in the grammatical structure of hadith, but in the meaning. Ibrahim Kurani should not give a large portion in responding the interpretation of literalists which is different from 'urafä.

${ }^{19}$ Seyyed Houseini Kouhsari, "Hakikat 'Irfan”, Kan₹ Pholosophia, Vol. 3, No. 2, December 2013, 244-245. 
Even at the beginning of Ithäf al-Dhakê, Ibrahim Kurani has claimed that every experience of 'urafā must be in accordance with the sacred text. The author is not trying to say that the experience of the'urafā need not be in accordance with the sacred text, but it should be noted that the 'urafa $\vec{a}$ s understanding of the sacred text with literalist's is certainly different. If imposing the 'urafä's experience to be viewed in literal perspective of understanding the scriptures, it would only be a theological judgement and assessment to Wahdatul Wujud.

So if a discrepancy between experience and understanding of ' $u r a f a{ }^{\prime}$ ' over the sacred text does not fit the theological perspective, it should not be decided that the experience of 'urafä is incompatible with the sacred text. Because the source of the difference is in the perspective of understanding of the sacred text. Theological judgments can not be the only path of truth because it depends heavily on the level of ability and perspective of understanding the sacred text.

In interpreting mubkamat and mutashabihat, 'urafā and theologians are different. ${ }^{20}$ The 'Urafa are of the opinion that all verses containedboth meanings of the mubkamat and mutashabibatat once. While the theologian categorizes certain verses as mubkamat and other verses as mutashabihat.

The scholars whose thought belongs to theological view pattern are generally literalistic. They use to interprete sharia from the literal viewpoint. On the other hand, sharia perspective often used to make judgments on Irfan. In this case, the problem is common, it depends upon how and what perspective will be used to interpret the sacred text,

${ }^{20}$ See Muhammad Nur, "Takwil dalam Pandangan Mulla Sadra", Kanz Philosophia, Vol. 2, No. 2, December 2012. 
because sharia is produced from the interpretation of the sacred text.

One of the consequences of interpreting the sacred text literally is the emergence of a paradox between one part and another. For example what Abu Hamid al-Ghazali declared in one passage that man should not take a negative view of the evil created by God. In this passage he accepts that it is true that God created evil. ${ }^{21}$ But on the other hand he says the evilcomes from a limited perspective of human. Due human failure to see things thoroughly so they give a negative judgment. In this passage, Abu Hamid alGhazali admits that evil is not from God but only human constructed judgment.

That is one of the paradoxical examples of the theologian. Then Ibrahim Kurani ${ }^{22}$ makes the synthesis of 'urafa and theologians based on the theologian's opinion which corresponds to 'urafäs. For, example, 'urafä does hold that evil is impossible created by God. So they believe that evil is only a human predication with their limitations.

Responding to those who hold that evil is real, Ibrahim Kurani argues that evil, like kufr, though it is in accordance with wisdom, but it is contrary to the Shari'a, then still causes the torment in the hell. With this conclusion, Ibrahim Kurani considers that wisdom is not in line with the Shari'a. This is part of the evidence that the Shari'a, especially the one that produced in the books of the schools of thought, is not an absolute truth. It is the result of the reduction of the sacred text by the cleric of the school and constructed in the conclusions of reason which subsequently the concession is called the Sharia of certain school.

\footnotetext{
${ }^{21}$ See Fritjof Scoun,. Islam dan Filsafat Perenial, (Bandung: Mizan, 1995).
}

${ }^{22}$ Oman Fathurrahman, Ithaf Al-Dhaki, 104-105. 
Thus it can be said that in general the theologian is often lead to paradoxes due to their literalistic mindset. But they still exist and are able to gain the sympathy of the majority of the people because of their simple pattern of teachings that can be understood easily by the general public. Even if there are some groups people who criticize their ideas, then easily the critic is crippled with ostracism, accusation of heresy, kufr, innovation and khurafat.

Throughout the history of Islamic civilization, there has been a great deal of confusion among literalists in theological and fiqh cases. The reasoning built is completely inconsistent. This is because the premises are based on a partial understanding of certain parts of the sacred text, not principled on the consistency of the principle of correct reasoning (logic).

Ibrahim Kurani said that kashaf is not the finalization of the provisions of the Shari'a. ${ }^{23}$ According to him, kashaf, refers to the experience of the prophet Muhammad is the beginning of the command of sharia. The problem is that the kashaf of the prophet cannot be equated with the kashaf of the 'urafä. After experiencing kashaf the prophets are burdened with the task to guide his people. While the 'urafa is not burdened with that. ${ }^{24}$

Hamzah Fansuri says that the Shari'a is the first path to kashaf. But in their condition of ecstacy, the 'urafä is unable to practice the Shari'ah because their reason is not working. Shari'a affirms reason. But once they return from ecstatic experience, there is no reason for them not to practice it. ${ }^{25}$

${ }^{23}$ Oman Fathurrahman, Ithaf Al-Dhaki, 109.

${ }^{24}$ See Muhammad Iqbal, Rekonstruksi Pemikiran Agama dalam Islam, transl. Huwasi and Musa Kazhim, (Bandung: Mizan, 2016), 153.

${ }^{25}$ See "Asrar al-Arifin", in Seyed Muhammad Naquib al-Attas, The Mysticism of Hamzah Fansûrî, (Kuala Lumpur: University of Malaya Press, 1970). 
The thing that is often questioned on 'urafä is, they no longer run the Shari'a in accordance with that genarally run in public. It should be understood on the ground that the Shari'a which is implemented collectively in society is the product of a particular school. Every true kashaf surely have to give a benefit to an 'urafa'. Perhaps one of the benefits is the consciousness that the true Shari'ah is not the consensus. With his experience, an 'arif must have had better knowledge than before. So they must understand the Shari'a better than the previous way. The implication is that the practice of Shari'a is different from before and not in accordance with conventionally practiced law.

People generally regard what is not in accordance with what they see as normal and as it is generally carried out by the general society isheresy and based on wrong faith. That's where the problem is. So the question of Sharia coherence and mystical experience of 'urafa is on the perception and prediction of the general public.

As it has been mentioned above that Ibrahim Kurani justifies only certain appropriate passage between 'urafä' and the theologians' teaching. Then interpret the teachings of 'irfan with theological perspective. This is what named as reduction. ${ }^{26}$ Or it could also be said as discrimination. Because actually the teachings of 'irfan with theology have different ontological and epistemological foundations. ${ }^{27}$

For example, Ibrahim Kurani quotes part of Junayd al-Baghdadi's statement that tawheed is separating the eternal from the transient. ${ }^{28}$ The meaning of 'eternal' and

${ }^{26}$ But the reduction is not an academic reduction as initiated by Mario Bunge. See, Cipta Bakti Gama, "Reduksionisme Eksplanatif untuk Antropologi Transendental Jawadi Amuli”, Kanz Pholosophia, Vol. 5, No. 2, 2015.

${ }^{27}$ Murtadha Mutahhari, Pengantar Epistemologi Islam, transl. Muhammad Javad Bafaqi, (Jakarta: Sadra Press, 2010), 100.

${ }^{28}$ Oman Fathurrahman, Ithaf Al-Dhaki, 115. 
the meaning of 'transient' itself in the view of 'urafā and theologians is different. For 'urafä, the transient is the nature. Nature for 'urafä is the shadow of Al-Haqq. As revealed by Hamzah Fansuri:

\section{Tertentu awwal suatu cahaya \\ Itulab cermin yang Mulia Raya \\ Kelibatan di sana miskin dan kaya \\ Menjadi dua Tuhan dan cahaya. ${ }^{29}$}

The first light has been certain

It is the mirror of The Great

Poor and rich is seen there

Becomes two, God and light.

Shadow has no existence. Shadows that do not have that existence of course depend absolutely on the owner of the shadow. ${ }^{30}$ But when a theologian tries to accept the 'urafâ' view, they will mean that nature depends absolutely upon Haqq 'Ta'ala.

Upon the phrase "depends absolutely" the 'urafa' and the theologioan have smilar view, both can accept the statement of the phrase. But the meaning understood by them is different. The phrase which is literally accepted by both 'urafā and theologian does not actually have a common meaning. When the theologian tries to understand the phrase he will interpret it with the perspective of a theologian. This is what Ibrahim Kuarani and Abdurrauf as-Singkili do as long as they discuss Wahdatul Wujud. The result is the reduction of irfan into the theological perspective.

${ }^{29}$ Seyed Muhammad Naquib al-Attas, The Mysticism of Hamzah Fansûrî, 260.

${ }^{30}$ William C. Chittick, Dunia Imajinal Ibnu 'Arabi, transl. Achmad Syahid, (Surabaya: Risalah Gusti, 2001), 32. 
The reduction of 'irfan into the theological perspective is a ruthlessness over Wahdatul Wujud. That is what is done in the whole Ithäf al-Dhakî. Ibrahim Kurani has difficulty in understanding the Absolute Haqq Ta'ala with a'yan tsabitah. He thinks that in 'irfan, the status of Absolute Substance of Haqq Ta'ala and a'yan tsabitah are the same. So he claimed that the movement or exchange applies to Haqq Ta'ala and also to the $a^{\prime}$ yan tsabitah whose movement is derived from the Absolute Substance, Haqq Ta'ala. ${ }^{31}$ To say that the movement of a'yan tsabitah originated from the exchange of Absolute Substance of Haqq Ta'ala is equal with acknowledging Haqq Ta'ala is not fixed so it raises the conclusion that Haqq Ta'ala is not perfect.

The problem arises from the ignorance or unwillingness to understand that Haqq Ta'ala in 'irfan is an Absolute Being that is no other being beside Him. This is what theologians would not accept including Ibrahim Kurani. He wants Haqq Ta'ala and universe (all other than Haqq Ta'ala) also has existence. But 'urafá does not view that way. For them all other than Haqq Ta'ala is just like a shadow. The shadow does not have its own form.

To the theologian, the word 'being' is equivocal in status, or it can be meant as compound. ${ }^{32}$ For example the word 'glass' which can mean either 'glass' or 'spectacles'. So they judge the word 'being' to be referred to 'Haqq Ta'ala' and can also be referred to 'universe'.

So to the theologian, the word being can be referred to God and can also be referred to universe. But 'urafā and some

${ }^{31}$ Oman Fathurrahman, Ithaf Al-Dhaki, 134.

32 Ismail Fahmi Arrauf Nasution, "Humanisasi Pendidikan Islam Melalui Antropologi Transendental Hamzah Fansuri", Edukasia, Vol. 12, No. 1, Februari 2017, 238. See also Abdul Hadi Fadl, Logika Praktis: Teknik Bernalar Benar, (Jakarta: Sadra Press, 2015), 14. 
philosophers have a different thought with the theologian. They understand the word being as univocal, a word that has only one reference to meaning. Then the word being for 'urafā referes only to Haqq Ta'ala, not others.

Since the theologians are of the opinion that 'being' is equivocal they believe that all entities like God, man, stone, table are the same 'being'. Like Ibrahim Kurani, he would have difficulty in understanding the statement of 'urafä, as Muhammad Fadhullah al-Burhanpuri's statement for instance, who believe that even atoms apart from 'being'. Everything is 'being'. Responding to such a statement, to say the unity as "... the relationship of the physical aspect of the Almighty Being, whereby all reality exist". ${ }^{33}$ So the unity understood by the theologians such as Ibrahim Kurani is due to the entities of the universe united on the ground that all are creation of God.

This kind of mindset emerges because the theologians have difficulties in distinguishing between wujüd (existence) and mabiyyah (whathness). ${ }^{34}$ Any entity other than Haqq Ta'ala, an example to the sensed entity, they think that the nine accidents captured from the entity can be named as wuju. ${ }^{35}$ Whereas the five substances and the nine accidents are not the being but the formation of mabiyah so that it becomes an entity (mahiyyah).

${ }^{33}$ Oman Fathurrahman, Ithaf Al-Dhaki, 136-137.

${ }^{34}$ The best reference to understanding wujud and mabiyah, See, Alparslan Acikgenc, Being and Existence in Sadra and Heidegger, (Kuala Lumpur: ISTAC, 1993), 74; Muhammad Taqi Misbah Yazdi, Buku Daras Filsafat Islam, transl. Musa Kazhim and Saleh Bagir, (Bandung: Mizan, 2003), 187; Toshihiko Isutzu, Struktur Metafisike Sabzawari, transl. O. Komarudin, (Bandung: Pustaka, 2003), 37.

${ }^{35}$ Regarding five substances and nine accidents, see Mohsen Gharawiyan, Pengantar Memahami Buku Daras Filsafat Islam, (Jakarta: Sadra Press, 2012). 
While to 'urafä and some philosophers, mabiyyah is only a shadow of wujüd, through mahiyyah we can know 'being'. ${ }^{36}$ Just like knowing there is a vehicle in the back through the rearview mirror.

One of the academic scrutiny that a scientist needs to address is the ability to sort things out. In discourse related to Islamic thought for example, the thoroughness of sorting between the philosophical, theological and mystical issues is very important. Otherwise, instead of being a problem solver as expected, the research raises new problems.

One of the core themes in Islamic thought is about wujüd, both conceptually and in reality. Therefore, the discourse of 'being' in philosophy, theology and mysticism can not be mixed. Even the manifestations for each sect in philosophy, theology and mysticism have different meanings. In philosophy for example, wujüd in the Masya'iyyah's school view is different from Isyraqiyah school and Hikmah Muta'alliyah school. Wujud in the view of philosophical Sufism is different from being in akblaqi sufism. Likewise wujūd in view of the school of Mu'tazila is different from 'being' in the view of Ash'ariah's school, and so on and so fort. So the concept of wujüd in each segment can not be generalized.

As written in the whole of Ithäf al-Dhakî, Ibrahim Kurani responds to Wahdatul Wujud with a less significant perspective. For example, in response to the discourse of separation of external beings and the concept of being, he took Abdurrahman Jami's opinion as a representation of 'urafä, then concludes the appropriateness of Abdurrahman Jami' with the philosophical view, especially the Masya'iyyah

${ }^{36}$ One of the philoshoper who has such opinion is Mulla Sadra. See, Fazlur Rahman, Filsafat Sadra, (Bandung: Pustaka, 2000). 
school. ${ }^{37}$ The inference is accurate. The problem is Ibrahim Kurani mixing up views of the separation of the concept of being and the reality of being in the perspective of philosophy and 'irfan. This kind of work really confuses society and intellectuals who have not really understood philosophy or 'irfan well. Moreover, many schools of philosophy are very similar to 'irfan.

"The existence of all things is the essence of reality," the statement said. The method of logical explanation of 'being' according to Ash'arism which was explained by Ibrahim Kurani is more similar to philosophical epistemology. ${ }^{38} \mathrm{He}$ says the unity of diversity of entities (as an explanation for acceptance of Wahdatul Wujud) is the identity of multiple entities with their source. The assumption: because it comes from the same source, of course, the diversity to some extend has similarities.

Such an assumption can be analogous to: if we are asked to look for similarities between a car, a house and a garden, then we answer the similarity of those objects is that those objects belong to same person. The similarity that Ibrahim Kurani refers to is not the similarity of reality as it is meant by 'urafa. The similarities he describes are more like the unity of each differensia because they come from the same genus. ${ }^{39}$

Such a reasoning model is probably a typical theory of theology. Describing diversity as unity in theology can not be attributed to the system of irfan which has a well-established

${ }^{37}$ Oman Fathurrahman, Ithaf Al-Dhaki, 140-143.

${ }^{38}$ Though can not be identified with any of philosophical school in Islam, or it may be the method of theological reasoning?

${ }^{39}$ Abdul Hadi Fadl, Logika Praktis: Teknik Bernalar Benar, (Jakarta: Sadra Press, 2015), 12. 
epistemology in explaining the case, generally the tajalli or ta'ayyun concentration, especially the a'yan tsabitab.

Ibrahim Kurani's opinion is based on the testament of Sayyidina Umar, "You should not stigmatize the words that come from a Muslim with bad assumsion, as far as you can produce a better interpretation for him." Based on that Ibrahim Kurani ventured to seek synthesis between irfan and Islamic theology (kalam).

But when examined epistemologically, the synthesis can not be academically and objectively justified. 'Irfan and kalam have different ontological and epistemological foundations. In constructing the synthesis, Ibrahim Kurani uses inconsistent terms and can not be agreed on the theological side or 'irfan.

The term Wajib al-Wujud (Necessary Being) in the epistemological study can not be regarded as the same meaning because it can damage a system of studies built. This is one of the epistemological and academic chaos perpetrated by Ibrahim Kurani. Uniquely in mixing views with the aim of justifying 'irfan', Ibrahim Kurani more often rejects the view of 'urafā whose thoughts are closer to Ibn' Arabi and Muhammad Fadhullah al-Burhanpuri and more receptive to the views of Ahlul Hadith, theologians and peripatetic philosophers.

For example he criticized the views of Mulla Taftazani who comment on the terminology of ittihad and bulül in the experience of 'urafát. Mulla Taftazani says the terminology is used because "... the limited expression to explain the situation." ${ }^{40}$ Mulla Taftazani, from the same source of quotation, also says "Discourse on this issue is very long, out of the logic of reason and shari'a." Ibrahim Kurani criticized it by saying that Mulla Taftazani's statement was incorrect by

${ }^{40}$ Oman Fathurrahman, Ithaf Al-Dhaki, 152. 
the reason that Mulla Taftazani was inconsistent because in the first part he said the termonology was used because of the limitations of the term that could be used, while in the second it said it was out of logic And Shari'a.

Whereas Ibrahim Kurani should have understood that Mulla Taftazani's intention was, the experience came out of the Shari'a when he was discussed, informed, communicated. So it is true that the experience is more beautiful as a feeling, not a proof.

To refute Mulla Taftazani's claim that the experience is out of logic, Ibrahim Kurani at length ${ }^{41}$ seeks to prove that the Absolute Being is not only applicable in the mental concept (wujûd dhihnî) but also exists in external reality (wujüd khariji). ${ }^{42}$ While Mulla Taftazani's intention is to discuss the Absolute Being in the context of mental concepts.

Ibrahim Kurani's panic occurs because, as a general theologian, he can not distinguish the discourse of being in mental concepts and external reality. Meanwhile, as an intellectual who mastered well the Masya'iyyah philosophy, Mulla Taftazani was able to differentiate the discourse of being in the mental concepts and the discourse of being in external reality. "Diversity is only on consciousness and manifestations that are at the level of imagination and fantasy," said Mulla Taftazani. And this statement is very

${ }^{41}$ One of intellectual abatement and lack of ability to make the category is due to lack of understanding. Though explaining 'irfan will not be useful by using epistemologi of Masya'iyyah. Similarly explaining theology will not provide significant benefits bythe use of Masya'yyah epistemology as did Seyed Muhammad Naquib Al-Attas. See, Seyed Muhammad Naquib Al-Attas, A Commentary on the Hutta Al-Siddiq of Nuruddin Ar-Raniri, (Kuala Lumpur: Ministry of Culture Malaysia, 1986), and many part in Seyed Muhammad Naquib Al-Attas, Comments on the Re-Examination of Al-Raniri's Huijatul Siddiq: A Refutation, (Kuala Lumpur: Muzium Negara Malaysia, 1975).

${ }^{42}$ Oman Fathurrahman, Ithaf Al-Dhaki, 166. 
synonymous with the views of 'urafa like Ibn' Arabi, ${ }^{43}$ Sayyid Haidar Amuli ${ }^{44}$ and Hamzah Fansuri.

\section{Revival of Wahdatul Wujud}

As explored above, it is clear that even though Ibrahim Kurani generally defends Wahdatul Wujud, but the epistemology used is irrelevant which reduce Wahdatul Wujud into the theological perspective. Thus, Ithäf al-Dhak $\hat{\imath}$ is completely unreliable to understand Wahdatul Wujud. Even the book is a discrimination against Wahdatul Wujud.

If we observe the chronology of the history of Islamic civilization in Aceh in particular, and the archipelago in general, the termination of Wahdatul Wujud was not only in the hands of Nur al-Din ar-Raniri due to his hard and sharp attacks ${ }^{45}$ The proof is that after Nur ad-Din ar-Raniri, Wahdatul Wujud is still existed and taught in Aceh. ${ }^{46}$

Unfortunately some societies conclude that the book, together with Abdurrauf as-Singkili's attitude to Wahdatul Wujud, is an ideal synthesis to reconcile Wahdatul Wujud with a literal theology. Yet they are all massive and systematic reductions of Wahdatul Wujud which ultimately brings to the termination of Wahdatul Wujud.

Wahdatul Wujud is a doctrine far from negative predictions. The teaching has shown inclusivity and is able to openly dialectise with various teachings. It has proven to mature the adherents of religion in thinking and acting.

${ }^{43}$ Ibnu Arabi, "Catur" Ilabi: Taktik Memenangkan Pergulatan Hidup, transl. Muhammad Ansor dan Moch. Mussofa Ihsan, (Jakarta: Hikmah, 2003), 48.

${ }^{44}$ Muhammad Nur, Wabdat al-Wujûd Ibn'Arabî dan Filsafat Wujûd Mulla Sadrâ, (Makassar: Chamran Press, 2012), 32.

${ }^{45}$ Nuruddin ar-Raniri, Tibyan fi Ma'rifah Al-Adyan Nuruddin Ar-Raniri, transl. Mohd. Kalam Daud (Banda Aceh: Pena, 2009), 216.

${ }^{46}$ Moreover, after Nuruddin ar-Raniri, the highest religious leader in Aceh was in the hand of the follower of Wahdatul Wujud namely Sayful Rijal from Minangkabau. See Azyumardi Azra, Jaringan, 242. 
Wahdatul Wujud is the solution to orthodox, literalist, extreme and radical attitudes.

The pluralism and inclusivism that the government and some intellectuals are socializing today do not have a clear and systematic ontological and epistemological basis. As a result, the government's campaigns are only able to be supported by money and spirit. Therefore, the government and some open-minded intellectuals who genuinely desire the realization of inclusiveness and plurality on a firm and systematic basis need to look back at Wahdatul Wujud from their reliable sources such as Ibn 'Arabi, Sayyid Haydar Amuli, Hamzah Fansuri and Syamsuddin as-Sumatrani.

In addition to that, the government has to find the youth of this nation who has a common view, intelligent, knowledgeable, consistent and inclusive to be able to study the classical treasure of irfan and embodied it in the context of society in the archipelago today in order to realize the continuation of a harmonious Islamic civilization, Inclusive dynamic and full of tolerant attitude. In this term that the revival of Wahdatul Wujud becomes relevant and significant.

\section{Conclusion}

Wahdatul Wujud is a doctrine that contains the principle of tolerance, dynamic, inclusive and able to unify all the differences. These principles have been proven in the history of Islamic civilization in Aceh until Iskandar Muda's time. It is also known that once the teachings are politically and intellectually suppressed, there is a lot of tension and even resulting in bloodshed in society.

In this brief article, more or less, the authors have pointed out that the abolition of Wahdatul Wujud from the history of Islamic civilization in Aceh, either roughly 
asconducted by Nur al-Din ar-Raniri or softly by Abdurrauf as-Singkili and Ibrahim Kurani, has made the Muslim community lose alternatives so they can not realize that orthodox teachings are not the only standard teachings in Islam.

The author has also shown that Wahdatul Wujud discrimination by Ibrahim Kurani is a study that is incompatible with the epistemology system and violates academic ethics. The book is also out of the purpose of it's creation that is to explain Wahdatul Wujud taught by Muhammad Fadhullah al-Burhanpuri.

Wahdatul Wujud needs to be revitalized as it can be a solution to the exclusive and radical understanding of Islam as it is common in Indonesia today. Wahdatul Wujud is a doctrine that is needed by Indonesian society to continue the chronology of peaceful and tolerant archipelago Islam that has been stalled due to the influx of foreign cultural influences that infiltrate the teachings of Islam so that the pattern of Islamic teaching is contrary to the life of the Archipelago nations, which is known for it's inclusiveness, permissiveness and democracy.

Thus the author expects the young intellectuals of the Archipelago to return to the scientific and academic studies of Wahdatul Wujud and find its relevance to the contemporary context so that it can be a solution for the Muslim community in particular, and the general human race, in order to create inclusiveness, tolerance and democracy towards a peaceful and harmonious Indonesia. 


\section{REFERENCES}

Acikgenc, Alparslan, Being and Existence in Sadra and Heidegger. Kuala Lumpur: ISTAC, 1993.

Abdullah, Taufik (ed.) Sejarah Umat Islam Indonesia. Jakarta: MUI, 1991.

Ahmad, Zakaria. Aceh Zaman Prasejarah \& Zaman Kuno. Banda Aceh: Pena, 2009.

al-Attas, Seyed Muhammad Naquib. The Mysticism of Hamzah Fansuri. Kuala Lumpur: University of Malaya Press, 1970.

- Comments on the Re-Examination of Al-Raniri's Hujjatu'l-Siddiq: A Refutation. Kuala Lumpur: Muzium Negara, 1975.

. The Concept of Education in Islam. ABIM: Kuala Lumpur, 1980.

- A Commentary on the Hujjat al-Shiddiq of Nur al-Din

al-Raniri. Kuala Lumpur: Ministry of Culture Malaysia, 1986.

- Islam dalam Sejarah dan Kebudayaan Melayu. Bandung: Mizan 1990.

. Historical Fact and Fiction. Kuala Lumpur: UTM Press, 2011.

Azra, Azyumardi. Jaringan Ulama: Timur Tengah dan Kepulauan Nusantara Abad XVII. Bandung: Mizan, 1999.

. Perspektif Islam di Asia Tenggara. Jakarta: Yayasan Obor Indonesia, 1989.

'Arabi, Ibn. "Catur" Ilabi: Taktik Memenangkan Pergulatan Hidup, transl. Muhammad Ansor and Moch Mussofa Ihsan. Jakarta: Hikmah, 2003. 
- Al-Futuhat Al-Makkiyyah: Risalah tentang Ma'rifah

Rahasia-rahasia Sang Raja dan Kerajaan-Nya, transl.

Harun Nur Rosyid. Yogyakarta: Darul Futuhat, 2016.

Chittick, William C. Dunia Imajinal Ibnu 'Arabî, transl. Achmad Syahid. Surabaya: Risalah Gusti, 2001.

ar-Raniri, Nuruddin. Tibyan fi Ma'rifah Al-Adyan Nuruddin Ar-

Raniri, transl. Mohd. Kalam Daud, Banda Aceh: Pena, 2009.

Fathurrahman, Oman. Ithaf al-Dhaki: Tafsir Wabdatul Wujûd bagi Muslim Nusantara. Jakarta: Mizan, 2012.

. Menyoal Wabdatul Wujûd: Kasus Abdurrauf Singkel di Aceh Abad XVII. Bandung: Mizan, 1999.

Fadli, Abdul Hadi. Logika Praktis: Teknik Bernalar Benar, transl. Muhammad Nur. Jakarta: Sadra Press, 2015.

Fang, Liau Yock. Sejarah Kesustraan Melayu Klasik. Jakarta: Erlangga, 1993.

Fazeli, Seyyed Ahmad. Mað̧bab Ibn Arabi: Mengurai Paradoksalitas Tasybih dan Tanzih, transl. Muhammad Nur. Jakarta: Sadra Press, 2016.

Gama, Cipta Bakti. "Reduksionisme Eksplanatif untuk Antropologi Transendental Jawadi Amuli", Kanz Pholosophia, Vol. 5, No. 2, December 2015.

Gharawiyan, Mohsen. Pengantar Memahami Buku Daras Filsafat Islam, transl. Muhammad Nur. Jakarta: Sadra Press, 2012.

Hadi, Abdul, WM and Ara LK (eds.). Hamzah Fansuri Bapak Sastra dan Bahasa Melayu. Jakarta: Lotlaka, 1981.

Hadi, Amirul. Aceh: Sejarah, Budaya dan Tradisi. Jakarta: Yayasan Pustaka Obor Indonesia, 2010.

Hasjmy, Ali. Ruba’i Hamzah Fansûrî. Kuala Lumpur: Dewan Bahasa dan Pustaka, 1976. 
- Bunga Rampai Revolusi dari Tanah Aceh. Jakarta: Bulan Bintang, 1978.

. Sejarah Masuk dan Berkembangnya Islam di Nusantara. Jakarta: Al-Ma'arif, 1998.

Houseini, Seyyed Kouhsari. "Hakikat 'Irfan”, Kanz Pholosophia, Vol. 3, No. 2, December 2013.

Hurgronje, Snouck. Aceh di Mata Kolonialis. Jakarta: Yayasan Soko Guru, 1985.

Iqbal, Muhammad. Rekonstruksi Pemikiran Religius dalam Islam, transl. Hawasi and Musa Kazhim. Bandung: Mizan, 2016.

Isutzu, Toshihiko. Struktur Metafisika Sabzawari, transl. O. Komarudin, Bandung: Pustaka, 2001.

Jami, Mawlana Abd ar-Rahman. Pancaran Ilahi Kaum Sufi, transl. Publisher Team. Yogyakrta: Pustaka Sufi, 2003.

Kasdi, Abdurrohman. "The Role of Walisongi in Developing Islam Nusantara", Jurnal Addin, Vol. 11, No. 1, February 2017.

Labib, Muhsin. Pemikiran Filsafat Ayatullah M.T. Misbah Yazdi. Jakarta: Sadra Press, 2011.

Lombard, Denys. Nusa Jawa: Silang Budaya Bagian 2 Jaringan Asia, transl. Winarsih Partaningrat Arifin. Jakarta: Gramedia, 2003.

Mutahhari, Murtadha. Pengantar Epistemologi Islam, transl. Muhammad Javad Bafaqi. Jakarta: Sadra Press, 2010.

Mulyati, Sri. Tasawuf Nusantara. Jakarta: Kencana, 2006.

Nasr, Seyyed Hossein. The Islamic Intellectial Tradition in Persia. New Delhi: Exel Books, 1996. 
(ed.). Ensiklopedi Tematis Spiritualitas Islam:

Manifestasi, transl. Mizan Translation Team. Bandung: Mizan, 2003.

Nasution, Ismail Fahmi Arrauf, "Mencerna Akar Filsafat dalam Islam“, Ulumuna, Vol. 17, No. 1, June 2013.

"Humanisasi Pendidikan Islam Melalui Antropologi Transendental Hamzah Fansuri”, Edukasia, Vol. 12, No. 1, February 2017.

Nur, Muhammad. Wabdat al-Wujud Ibn Arabi dan Filsafat Wujud Mulla Sadra. Makassar: Chamran Press, 2012. . "Takwil dalam Pandangan Mulla Sadra", Kan₹ Philosophia, Vol. 2, No. 2, December 2012.

Rahman, Fazlur. Filsafat Shadra, transl. Munir A. Muin and Ammar Haryono. Bandung: Pustaka, 2000.

Rostaria, Eri. "Hubungan Islamisasi Pendidikan Islam pada Masa Kesultanan Aceh", Studia Islamica, Vol. 3, No. 1, 1996.

Said, Muhammad. Aceh Sepanjang Abad, Vol. I, Medan: n.p., n.d.

Schoun, Fritjof. Islam dan Filsafat Perenial, transl. Rahmi Astuti. Bandung: Mizan, 1995.

Soelaiman, Darwis A. (ed.). Warisan Budaya Melayu-Aceh. Banda Aceh: PUSMA, 2003.

Sufi, Rusdi and Agus Bidi Wibowo. Rajah dan Ažimat pada Masyarakat Aceh. Banda Aceh: Badan Perpustakaan Provinsi Aceh, 2007.

Ula, Miftahul. "Simbilisme Bahasa Sufi: Kajian Hermeunetika terhadap Puisi Hamzah Fansuri", Religia, Vol. 19, No. 2, October 2015. 
Wijaya, Aksin, "Hermeunetika Al-Qur'an: Memburu Pesan Manusiawi dalam Al-Qur'an”, Ulumuna, Vol. 15, No. 2, December 2011.

Yahya, Mahayuddin. Sejarah Islam. Shah Alam: Fajar Bakti, 1999.

Yazdi, Muhammad Taqi Misbah. Buku Daras Filsafat Islam, transl. Musa Kazim and Saleh Bagir. Bandung: Mizan, 2003.

Zainuddin, H.M. Tarikh Aceb dan Nusantara. Banda Aceh: LSKPM, 2012.

Zein, Hamid Nasuhi. "Al-Tasawwuf wa al-Turuq al-Sufiyyah fi Indunisiya”, Studia Islamica, Vol. 3, No. 3, 1996. 
